\title{
Evidence for Fluid-Phase Pinocytosis of Extrahepatic Bile Duct Cells Isolated from Normal Rats in Culture
}

\author{
Gen Yamada ${ }^{1,2 \dagger}$, Norimasa Sawada ${ }^{1}$, and Michio Mori ${ }^{1}$ \\ ${ }^{1}$ Departments of Pathology and ${ }^{2}$ Internal Medicine, Sapporo Medical College, S.1, W.17, Chuo-ku, Sapporo \\ 060, Japan
}

\begin{abstract}
$A B S T R A C T$. In order to elucidate the physiological function of extrahepatic bile duct cells, we isolated epithelial cells from the rat extrahepatic bile duct by digesting resected segments of the extrahepatic bile duct with $0.15 \%$ trypsin in ice-cold $\mathrm{Ca}^{2+}$-free Hanks' balanced salt solution supplemented with 0.25 mM EDTA overnight. As a result, the epithelial cells were collected as aggregates and attached to culture dishes coated with type I collagen. Approximately $95 \%$ of the cells cultured for $24 \mathrm{hrs}$ were found to be positive for $\gamma$-glutamyl transpeptidase and cytokeratin-19, but negative for vimentin. These characteristics were identical to the features of rat extrahepatic biliary epithelial cells in situ. Ultrastructurally, the cells were long and columnar in configuration on the 2nd day in culture, and possessed numerous microvilli at the apical surface and well-developed junctional complexes at the lateral surface. These findings also indicate that the cells maintain an epithelial nature and are morphologically polarized. When the cells were exposed to a low dose of horseradish peroxidase (HRP) on the 2nd day in culture, which was followed by fixation and treatment with 3-3'-diaminobenzidine, HRP was found preferentially in the cytoplasmic vesicles near the apical surface. HRP was then observed in the intercellular spaces; however, the electron-dense tracer, ruthenium red, did not permeate into the intercellular spaces, and HRP was found in neither cytoplasms nor intercellular spaces when the cells were incubated in HRP-containing medium at $4^{\circ} \mathrm{C}$ for $30 \mathrm{~min}$. These results suggest that the extrahepatic bile duct epithelial cells are involved in the reabsorption of bile constituents.
\end{abstract}

The bile duct system of rat consists of the bile canaliculi, canal of Hering, bile ductules, interlobular bile ducts, septal bile ducts, intrahepatic bile ducts, and the extrahepatic bile ducts (common bile ducts).

The bile canaliculus is a narrow channel formed by hepatocyte plasma membrane between two or three neighboring hepatocytes. Contribution of the bile canaliculus to the bile flow through periodic contraction of the channel was suggested by experiments using isolated rat hepatocyte couplets in culture with time-lapse phase contrast microscopy $(11,18)$. This function of the bile canaliculus was verified recently by direct observation of bile canalicular contraction in a living rat, supporting its physiological contribution to bile flow in the liver (17).

Although the bile duct epithelial cells are considered to be implicated in the absorptive function of macromolecules of the bile $(1,4,6,7,19)$, studies of the synthesis of cholesterol and conjugation of hydrophobic bile acids (5) have never explored any further than the intrahepatic bile ducts. Therefore, the physiological

\footnotetext{
$\dagger$ Address for correspondence.
}

functions of the extrahepatic bile duct have remained unknown (14), except for the secreting function of the common bile duct in the rabbit (2). In the present study, we isolated the extrahepatic bile duct cells from normal rats and cultured them in an attempt to examine the $a b-$ sorptive function of the extrahepatic biliary epithelial cells.

\section{MATERIALS AND METHODS}

Isolation of extrahepatic bile duct cells. Male rats of Wistar strain, weighing about $350 \mathrm{~g}$, were fed a standard laboratory diet ad libitum. Four rats were sacrificed in each isolation procedure. Under pentobarbital anesthesia $(50 \mathrm{mg} / \mathrm{kg}$, i.p.), extrahepatic bile ducts were resected longitudinally, opened, and rinsed with $\mathrm{Ca}^{2+}$-free Hanks' balanced salt solution (HBSS). They were minced in HBSS containing one of the following enzymes or combinations: (a) $0.25 \%$ trypsin (Gibco Laboratories, USA), (b) $0.15 \%$ trypsin, (c) $0.05 \%$ tryp$\sin$, (d) $0.25 \%$ trypsin and $0.25 \mathrm{mM}$ disodium ethylenediaminetetraacetic acid (EDTA; Katayama Chemical), (e) $0.15 \%$ trypsin and $0.25 \mathrm{mM}$ EDTA, (f) $0.05 \%$ trypsin and $0.25 \mathrm{mM}$ EDTA, (g) $0.05 \%$ collagenase (Yakult Pharmaceutical) and 
$0.1 \%$ dispase (Godo Shusei).

After overnight enzyme digestion at $4^{\circ} \mathrm{C}$, the cells were collected by centrifugation at $160 \times \mathrm{g}$ for $5 \mathrm{~min}$. The pellets were suspended in $10 \mathrm{ml}$ of Dulbecco's modified Eagle's medium (Nissui Pharmaceutical) and mixed with an equal volume of Ham's medium F-12 (Kyokuto Pharmaceutical) supplemented with $10 \%(\mathrm{v} / \mathrm{v})$ fetal calf serum (Filtron, Australia), 100 units penicillin $\mathrm{G} / \mathrm{ml}, 100 \mu \mathrm{g}$ streptomycin/ml (Gibco), $10^{-7} \mathrm{M}$ dexamethasone (Sigma Chemical Co., USA), $5 \mu \mathrm{g}$ insulin $/ \mathrm{ml}, 5 \mu \mathrm{g}$ transferrin $/ \mathrm{ml}, 5 \mu \mathrm{g}$ selenious acid/ml (ITS; Collaborative Research Inc., USA), $10 \mathrm{mM}$ nicotinamide (Sigma), $10 \mathrm{mM} \mathrm{N}$-2-hydroxyethylpiperazine- $\mathrm{N}^{\prime}$-ethane sulfonic acid (HEPES; Sigma) and 0.1\% albumin (Sigma).

The cells were seeded onto $35 \mathrm{~mm}$ culture dishes coated with type I collagen at a density of $20 \mu \mathrm{g} / \mathrm{dish}$. The cell number and viability were examined using $0.15 \%$ trypan blue in saline and counted in a hemocytometer. Cell attachment was determined by the number of cell sheets observed in ten $4 \mathrm{~mm}^{2}$ areas of each dish on the 2 nd day after plating. Contamination of fibroblasts was checked on the 2nd day of culture.

To examine the effects of substrata on the cell attachment, the following coating substances were employed: type I collagen (Vitrogen 100; Collagen Corp., USA), type IV collagen (Nittazeratin Corp.), fibronectin, and laminin (Nittazeratin).

Enzyme cytochemistry and immunocytochemistry. After being cultured for 2 days, the cells were fixed in acetone at $4^{\circ} \mathrm{C}$ for $30 \mathrm{~min}$ for cytochemical and immunocytochemical demonstrations of $\gamma$-glutamyl transpeptidase (GGT), cytokeratin-19 (CK-19) and vimentin.

GGT activity was examined according to the method of Rutenberg et al. (12).

For immunocytochemical detection of CK-19 and vimentin, the fixed cells were incubated for $6 \mathrm{hrs}$ at room temperature with mouse anti-CK-19 monoclonal antibody (Amersham, UK) diluted to $1: 100$ with phosphate-buffered saline (PBS) or with mouse anti-vimentin monoclonal antibody (Dako, Denmark) diluted to 1:100 with PBS. The cells were
Table II. EFFBct of SUbStRata ON Cell StTAChment.

\begin{tabular}{lcc}
\hline substrata & amount per dish $(\mu \mathrm{g})$ & attachment $^{1)}$ \\
\hline type I collagen & 20 & $8.2 \pm 2.17$ \\
type IV collagen & 20 & $6.8 \pm 1.19$ \\
fibronectin & 20 & $1.5 \pm 0.49$ \\
laminin & 20 & $0.8 \pm 0.65$ \\
\hline
\end{tabular}

1) the mean number of attached monolayer sheets $\pm \mathrm{SD}$ in $4 \mathrm{~mm}^{2}$ at 15 random places in the culture dish on the 2 nd day of culture.

then reincubated for $1 \mathrm{hr}$ with fluorescein isothiocyanate (FITC)-conjugated rabbit anti-mouse IgG antibody (Dako) diluted to $1: 100$ with PBS, and examined by a fluorescence microscope.

GGT activity, and expressions of CK-19 and vimentin in rat extrahepatic bile duct in situ were examined basically in the same way as described above.

Immunofluorescent study of tight junctions in the cultured cells. The monolayer formed on the 2 nd day in culture was fixed in methanol at $-20^{\circ} \mathrm{C}$ for $3 \mathrm{~min}$ and incubated with anti-ZO-1 monoclonal antibody (Chemicon International, Inc., USA) for $2 \mathrm{hrs}$ at room temperature, followed by incubation for $1 \mathrm{hr}$ with FITC-conjugated rabbit anti-rat IgG antibody (Dako) diluted to $1: 100$ with PBS for the examination by fluorescent microscopy. The antibody was shown to react with the $\mathrm{ZO}-1$ protein of $225 \mathrm{kD}$ localized preferentially at the tight junction (15).

Autoradiography using [methyl- $\left.{ }^{3} \mathrm{H}\right]$ thymidine. For an examination of cell proliferative activity, $1 \mu \mathrm{Ci}\left[{ }^{3} \mathrm{H}\right]$ thymidine $/ \mathrm{ml}$ was added to the culture media at the $48 \mathrm{th} \mathrm{hr}$ after plating.

The cells were further cultured in the media for $2 \mathrm{hrs}$, fixed in chilled $95 \%$ ethanol, and covered with a photographic emulsion (NR-M2; Konica Co.). After exposure in a cold dark room for 1 week, the cells were processed for development.

Ultrastructural study. For transmission electron micros-

Table I. Comparison of isolation PROCEdURES.

\begin{tabular}{|c|c|c|c|c|c|}
\hline enzyme & $\begin{array}{c}\text { cell number } \\
\left(\times 10^{6}\right)\end{array}$ & $\begin{array}{c}\text { viability } \\
(\%)\end{array}$ & attachment ${ }^{1)}$ & fibroblast $^{2)}(\%)$ & $\mathrm{N}^{37}$ \\
\hline (1) $0.25 \%$ trypsin & $0.2-0.3$ & $50-90$ & $(+)$ & less than $5 \%$ & 3 \\
\hline (2) $0.15 \%$ trypsin & $1.0-1.5$ & $60-90$ & $(+)$ & less than $5 \%$ & 3 \\
\hline (3) $0.05 \%$ trypsin & $<0.1$ & $\mathrm{ND}^{4)}$ & ND & ND & 2 \\
\hline (4) $0.25 \%$ trypsin- $0.25 \mathrm{mM}$ EDTA & $0.1-0.3$ & $40-70$ & $(+)$ & less than $5 \%$ & 3 \\
\hline (5) $0.15 \%$ trypsin- $0.25 \mathrm{mM}$ EDTA & $1.2-2.0$ & $80-95$ & $(H)$ & less than $5 \%$ & 4 \\
\hline (6) $0.05 \%$ trypsin- $0.25 \mathrm{mM}$ EDTA & $0.2-0.4$ & $80-95$ & $(H)$ & less than $5 \%$ & 3 \\
\hline (7) $0.05 \%$ collagenase- $0.1 \%$ dispase & $0.6-1.0$ & $80-90$ & $(H)$ & approx. $10 \%$ & 3 \\
\hline
\end{tabular}

Effects of enzyme digestion procedures on viable cell number, viability, attachment and fibroblast contamination. The attachment was evaluated on collagen type I-coated dishes.

1) indicated by the number of cell sheets found in $4 \mathrm{~mm}^{2}$ areas of the culture dish at the $2 \mathrm{nd}$ day of culture.

$(+)$ : less than 1 sheet $(H): 1$ to 5 sheets $(H H)$ : more than 5 sheets

2) ratio of contaminated fibroblasts to bile duct epithelial cells counted at the 2 nd day of culture.

3) number of experiments.

4) not determined. 


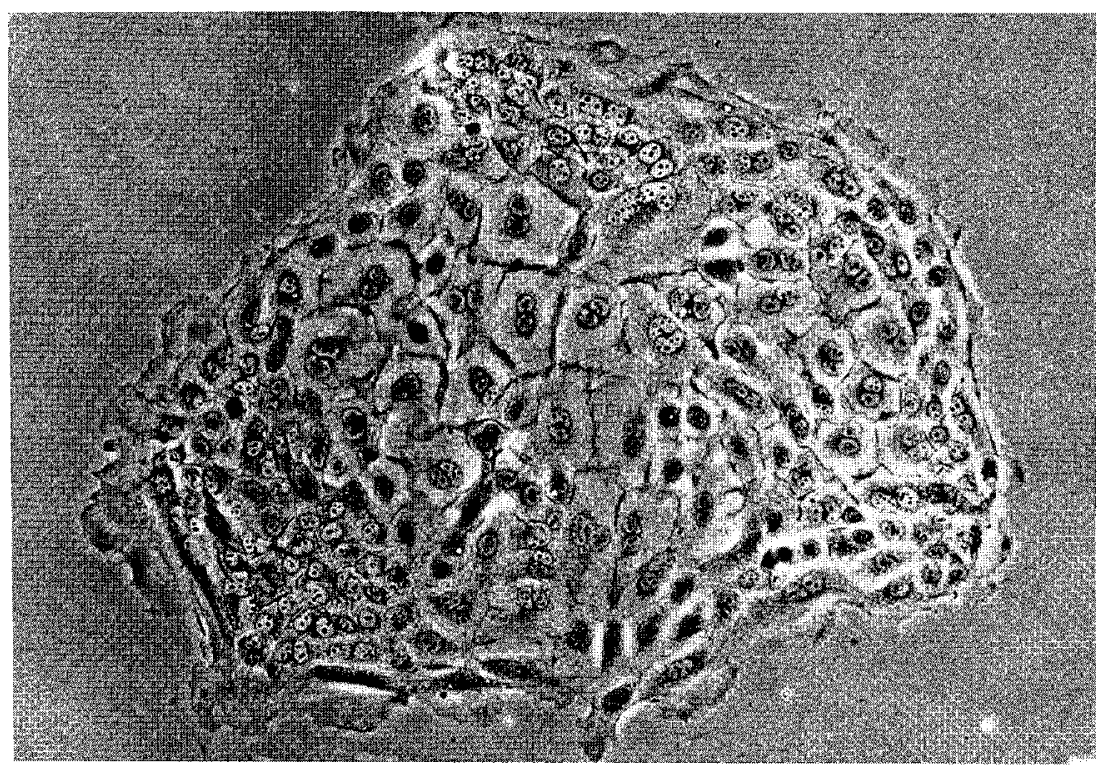

Fig. 1. Phase contrast photomicrograph of a cell sheet formed by rat extrahepatic bile duct cells at the 2 nd day of culture $(\times 85)$.

copy, the cells were fixed in $1 \%$ glutaraldehyde and $4 \%$ paraformaldehyde adjusted to $\mathrm{pH} 7.4$ with $0.1 \mathrm{M}$ cacodylate buffer at $4^{\circ} \mathrm{C}$ for $30 \mathrm{~min}$ either immediately after plating or after 2 days in culture. They were then postfixed with $1 \%$ $\mathrm{OsO}_{4}$, dehydrated, and embedded in Epon 812.

Ultrathin sections were stained with uranyl acetate and lead citrate, and examined by a JEOL $1200-E X$ or a JEM 100-BTR transmission electron microscope.

For the examination of the permeability barrier of these cells, ruthenium red (RR) staining was used. The cultured cells were fixed with $1 \%$ glutaraldehyde and $4 \%$ paraformaldehyde containing $1.5 \mathrm{mg} / \mathrm{ml} \mathrm{RR}$ at $4^{\circ} \mathrm{C}$ for $2 \mathrm{hrs}$, which was followed by fixation with $1 \% \mathrm{OsO}_{4}$ containing $1.5 \mathrm{mg} / \mathrm{ml} \mathrm{RR}$ for $1 \mathrm{hr}$. They were then processed for transmission electron microscopy as described above.

For scanning electron microscopy, on the 2nd day in culture the cells were fixed for $12 \mathrm{hrs}$ in $1 \%$ glutaraldehyde and $4 \%$ paraformaldehyde, immersed for $1 \mathrm{hr}$ in $2 \%$ tannic acid

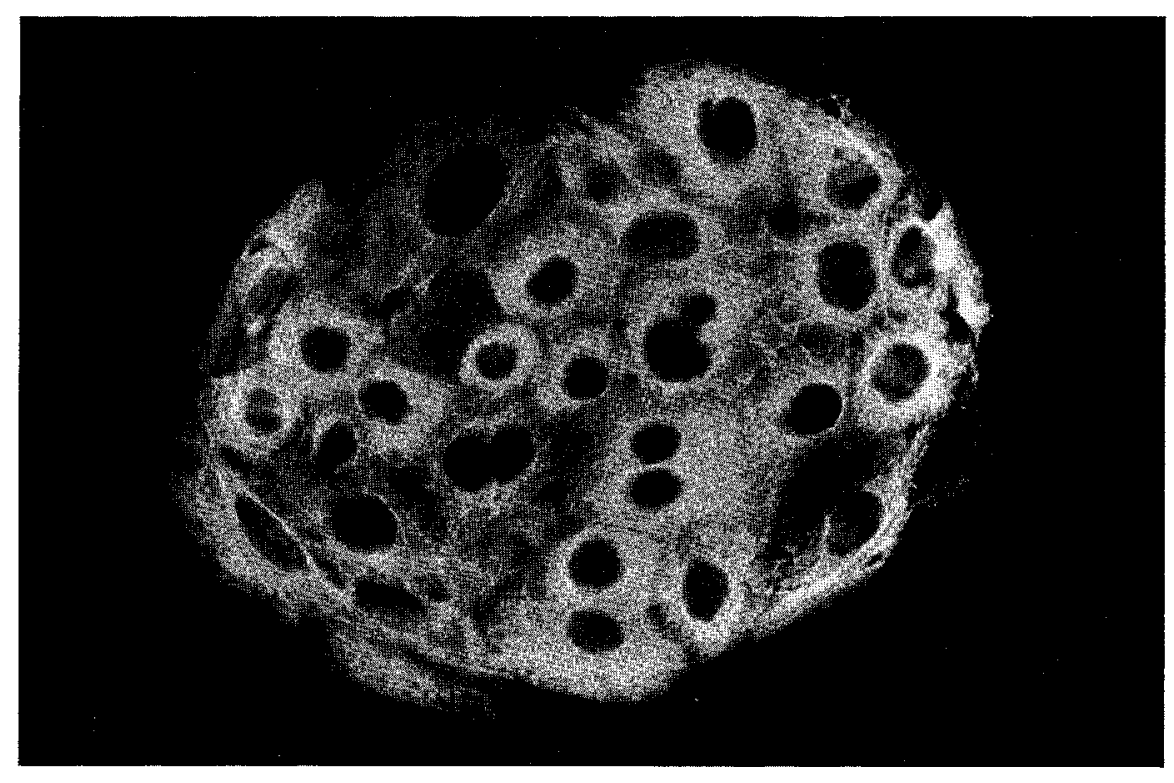

Fig. 2. CK-19 immunocytochemistry of the extrahepatic bile duct cells at the 2 nd day of culture $(\times 170)$. 
solution, and postfixed with $1 \% \mathrm{OsO}_{4}$ for $1 \mathrm{hr}$.

After rinsing, they were dehydrated in a graded series of ethanol, and immersed in t-butyl alcohol. After drying in the JFD-300 freeze-drying device, specimens were coated with platinum-palladium and examined by means of an S-570 scanning electron microscope.

HRP uptake study. On the 2 nd day of culture, the cells were exposed to HRP (type II, Sigma) which was added to the culture media at a concentration of $1 \mathrm{mg} / \mathrm{ml}$ for $5,15,30 \mathrm{~min}$ at $37^{\circ} \mathrm{C}$ or $4^{\circ} \mathrm{C}$. The incubation was stopped at the start of fixation with $1 \%$ glutaraldehyde and $4 \%$ paraformaldehyde for $30 \mathrm{~min}$ at $4^{\circ} \mathrm{C}$. After washing with PBS, the cells were incubated for $60 \mathrm{~min}$ at $37^{\circ} \mathrm{C}$ in a solution containing 0.2 $\mathrm{mg} / \mathrm{ml} \mathrm{3,3}$-diaminobenzidine tetrahydrochloride (DAB; Sigma) and $0.01 \% \mathrm{H}_{2} \mathrm{O}_{2}$ in $0.05 \mathrm{M}$ Tris- $\mathrm{HCl}$ buffer, $\mathrm{pH}$ 7.6. They were fixed with $1 \% \mathrm{OsO}_{4}$ for $1 \mathrm{hr}$ and processed for transmission electron microscopy as described previously (10).

\section{RESULTS}

Comparison of the isolation procedures. Among the conditions tested in the present study, the combination of $0.15 \%$ trypsin and $0.25 \mathrm{mM}$ EDTA gave the best result in terms of number of cells yielded attachment to the culture dishes (Table I).

In contrast, treating the bile duct with $0.25 \%$ trypsin, $0.25 \%$ trypsin and $0.25 \mathrm{mM}$ EDTA, or $0.05 \%$ trypsin and $0.25 \mathrm{mM}$ EDTA yielded only small numbers of viable cells. Treatment with $0.15 \%$ trypsin also resulted in inconsistent viability, and a low concentration of tryp$\sin (0.05 \%)$ yielded the least viable cells. The cells obtained with $0.05 \%$ collagenase and $0.1 \%$ dispase diges-

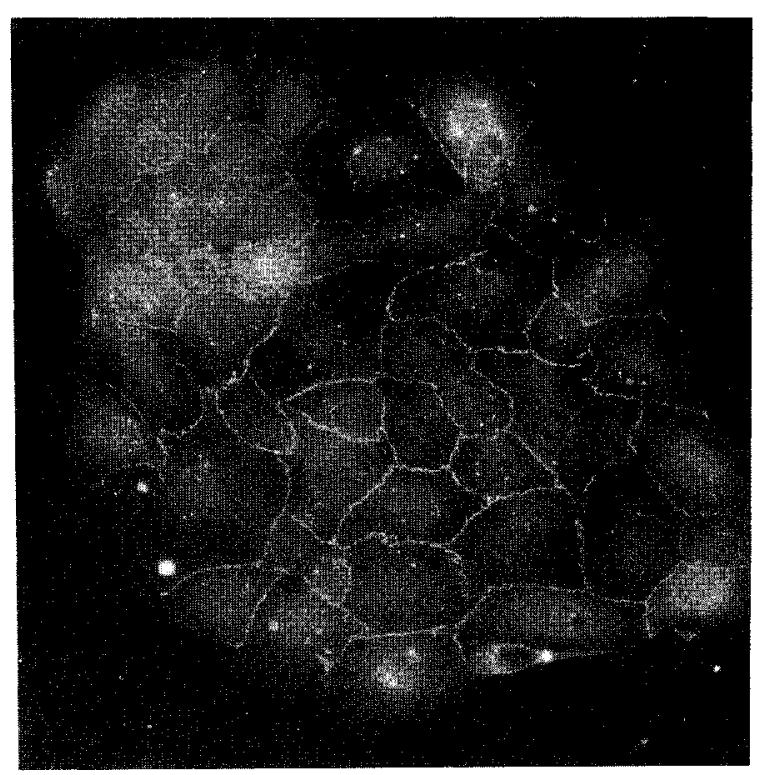

Fig. 3. Immunofluorescent demonstration of tight junctions in the extrahepatic bile duct cells at the 2 nd day of culture. Honeycomb-like structures are clearly seen along the cell boundary $(\times 118)$.

tion were greatly contaminated with fibroblasts. Short incubation ( 1 or $3 \mathrm{hrs}$ at $37^{\circ} \mathrm{C}$ ) of the bile duct in the above-mentioned enzyme solutions did not yield enough cells for the attachment assay (data not shown).

Effects of substrata on cell attachment. In order to collect isolated epithelial cells effectively, first, we examined the effects of various substrata on cell attachment. When the isolated cell aggregates were plated on the culture dishes coated with type I or type IV collagen, they

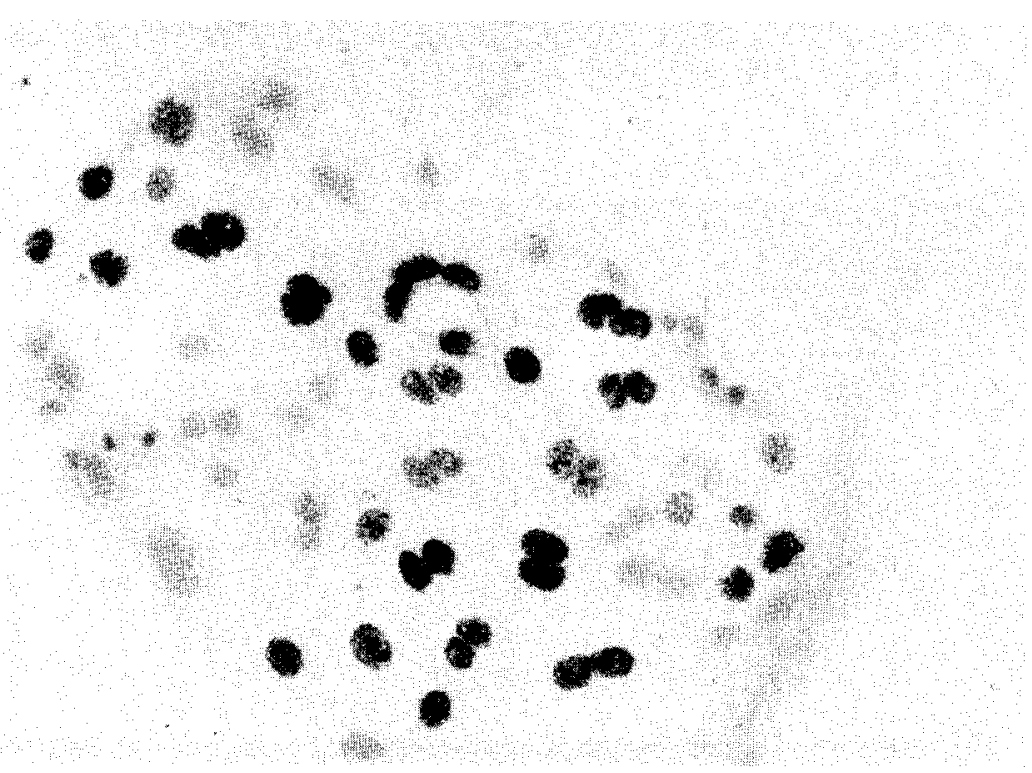

Fig. 4. ${ }^{3}$ H-thymidine autoradiograph of the extrahepatic bile duct cells at the 2 nd day in culture (counterstained by hematoxylin, $x 118$ ). 

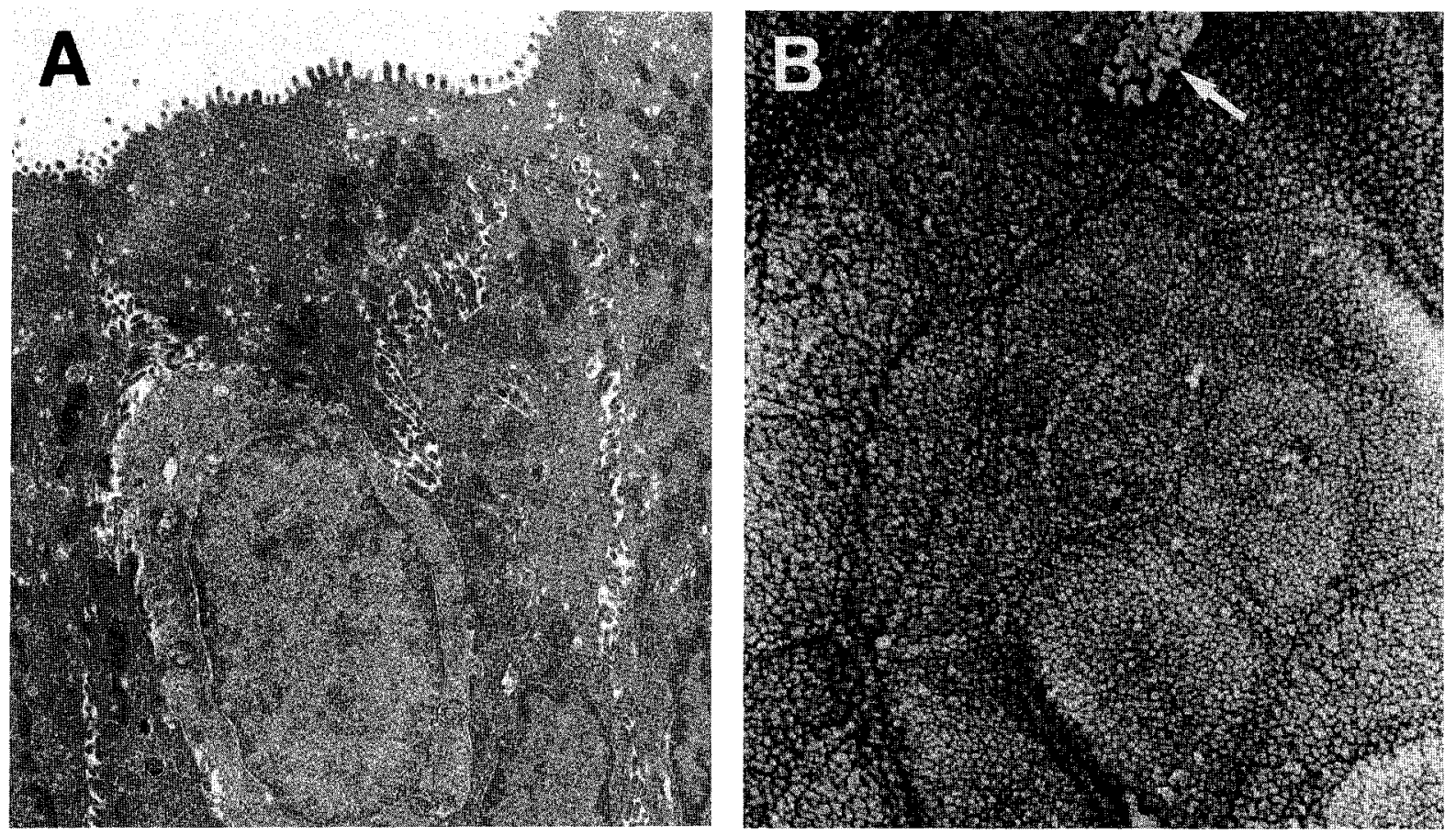

Fig. 5. Transmission (A) and scanning (B) electron micrographs of the rat extrahepatic bile duct epithelial celis in situ. Small vesicles are observed at the apical portion (A). Numerous short microvilli are observed at the cell surface (B, arrow: brush cell) (A: $\times 6400$, B: $\times 8400)$.

attached well to the substrata. On the other hand, the cell aggregates did not attach adequately to dishes coated with fibronectin or laminin (Table II).

By the 24 th hr of culture, the cells had spread on the collagen-coated dishes and had formed small monolayered cell sheets. The cells located in the center of the cell sheet were hexagonal or pentagonal in shape, whereas those in the periphery of the cell sheet were irregularly shaped (Fig. 1).

Cytochemical and immunocytochemical characteristics of the cultured cells. More than $95 \%$ of the cells were shown to be positive for GGT histochemistry (data not shown) and CK-19 immunocytochemistry (Fig. 2), and were negative for vimentin immunocytochemistry. The cultured cells showed characteristics similar to rat extrahepatic bile duct epithelial cells in situ.

Immunofluorescent demonstration of tight junctions in the cultured cells. Honeycomb-like networks of immunofluorescence were observed in the cells on the 2nd day of culture when they were treated with the anti-ZO1 antibody (Fig. 3). Such networks of immunofluorescence were found at the site of cell-cell contact, and were clearly seen only when the focus was adjusted near the apical surface of the cells, which suggests that the tight junction is present in the apical portion of the cell boundary.

Cell proliferation activity. Incorporation of $\left[{ }^{3} \mathrm{H}\right]$ thymidine was observed in $50 \%$ to $60 \%$ of the cells cul- tured in vitro for $48 \mathrm{hrs}$ (Fig. 4). No difference was observed in the distribution pattern of labeled cells in

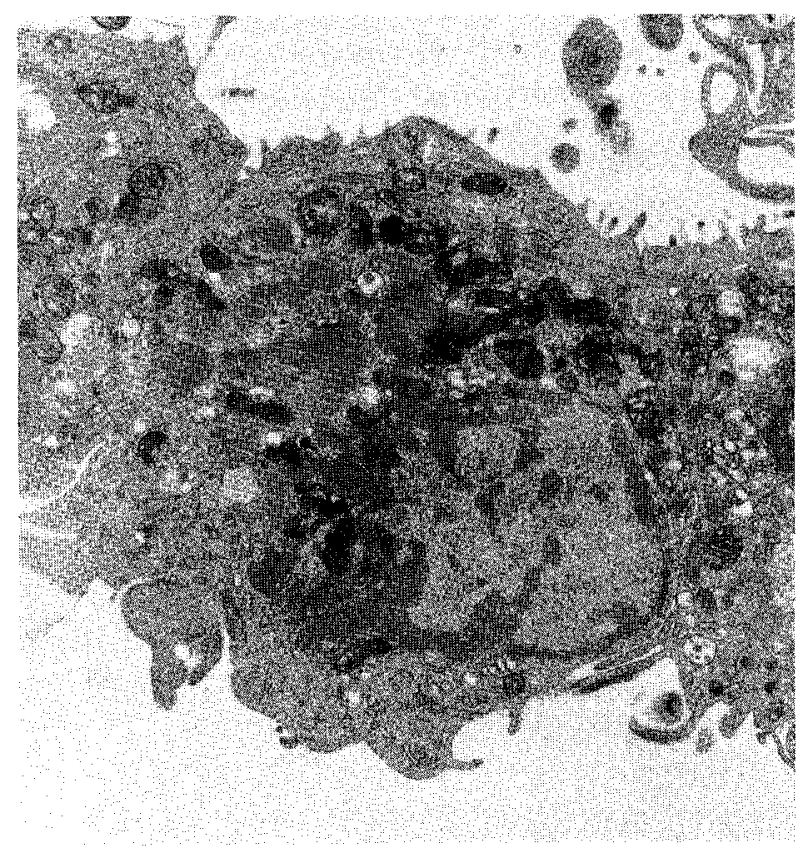

Fig. 6. Transmission electron micrograph of isolated cells before plating. Short microvilli are found at the upper side of the cell, whereas the nucleus is located at the bottom of the cell $(\times 8,000)$. 
the periphery or the center of the cell sheet. However, after 6 to 8 days of culture, such proliferation activity was no longer found, and the cells gradually detached from the culture dishes after 8 days in culture.

Ultrastructure of rat extrahepatic bile duct epithelium in situ. The extrahepatic bile duct in situ was lined with a single layer of tall columnar epithelial cells. $\mathrm{Nu}-$ merous microvilli were found at the apical surface, and junctional complexes were found at the cell boundary. Intracytoplasmic organelles were scant, but smooth-surfaced vesicles were often observed in the cytoplasm near the luminal surface (Fig. 5A). Scanning electron microscopy revealed the presence of brush cells, characterized by long "brush-like" microvilli, among the epithelial
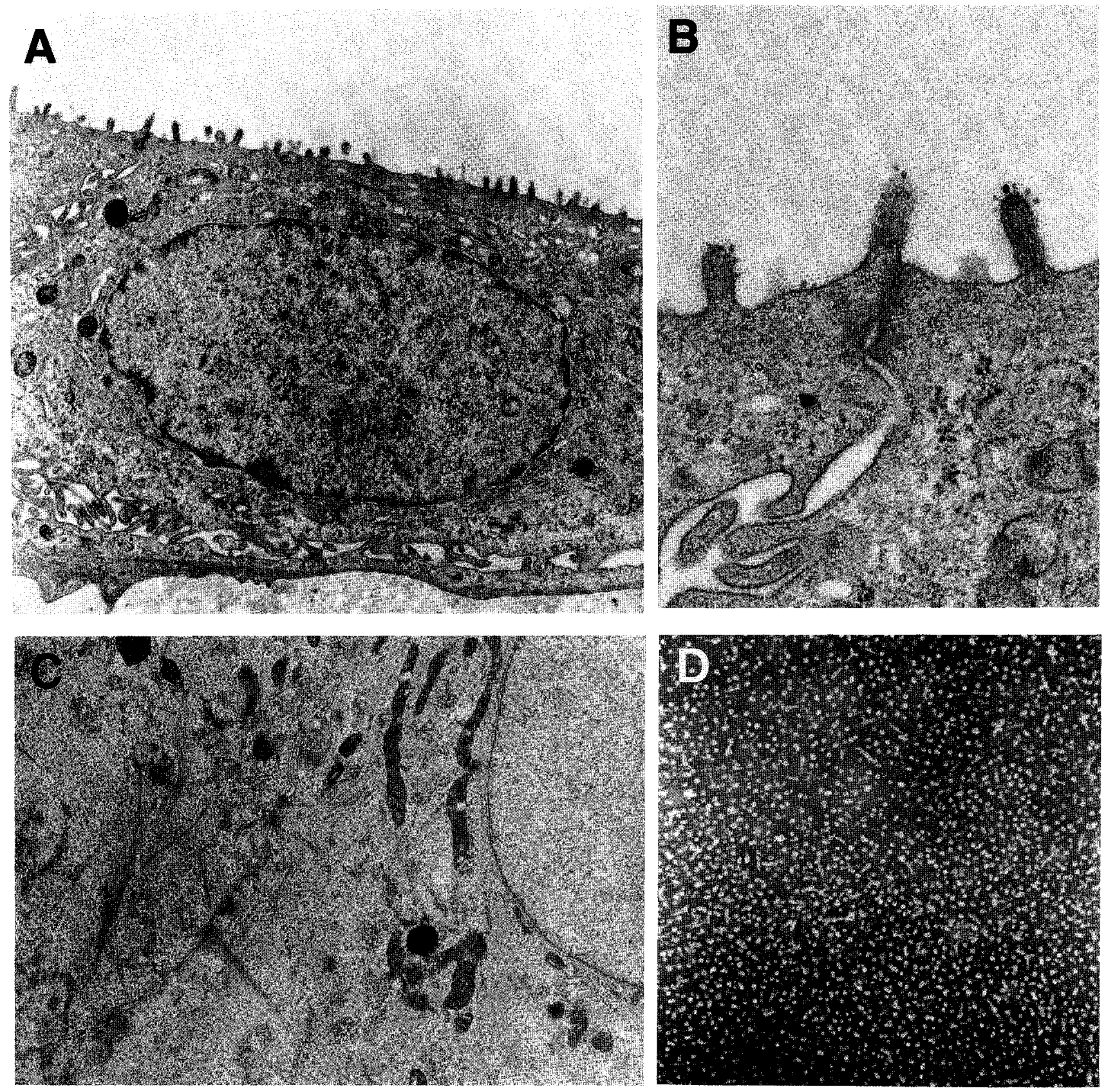

Fig. 7. Transmission (A-C) and scanning (D) electron micrographs of the cells at the 2 nd day of culture. Large nucleus (A and C), and abundant cytoskeletal filaments in the cytoplasm (C) are seen. Tight junctions are observed at the apical portion of the cell boundary (B). Numerous microvilli are observed on the cell surface (D) $(A: \times 11,400, B: \times 57,000, C: \times 11,400, \mathrm{D}: \times 8,500)$. 


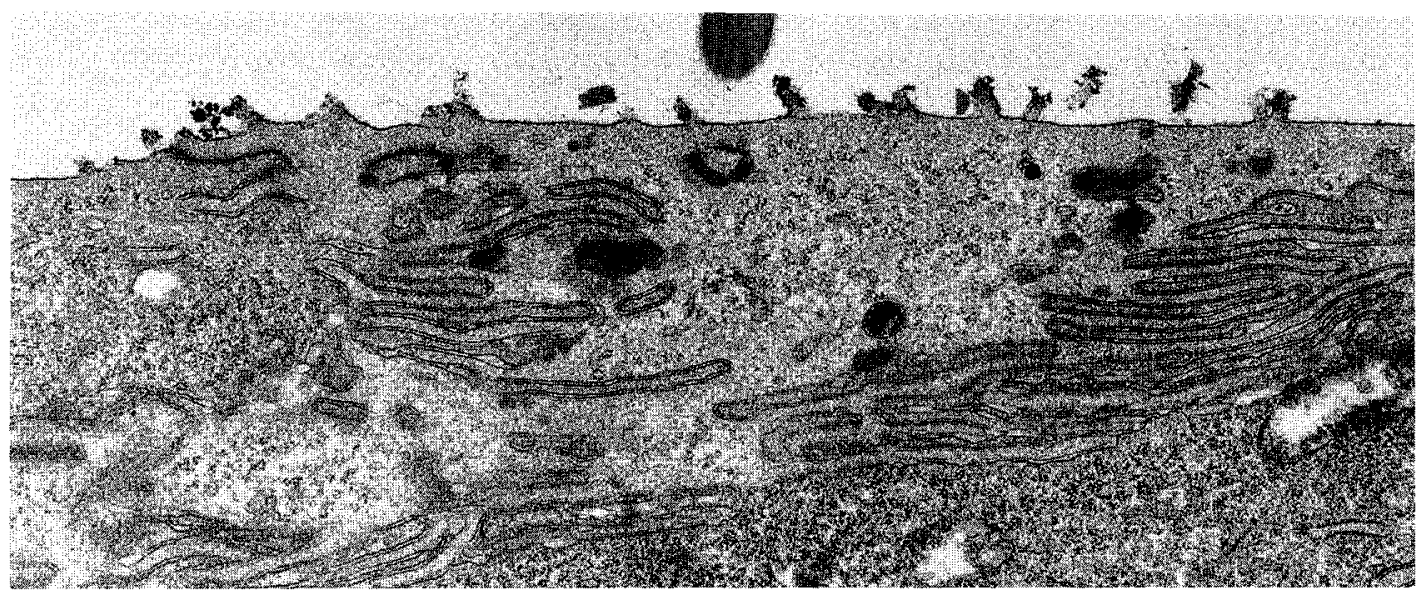

Fig. 8. Electron micrograph of the bile duct cells at the 2 nd day in culture treated with RR. Electron-dense RR is seen over the plasma membrane, but not in the intercellular spaces $(\times 17,000)$.

cells of the mucosa (Fig. 5B arrow).

Ultrastructural observation of the cultured cells. Electron microscopically, the isolated cells were shown to be connected with each other by junctional complexes before plating (Fig. 6). They had microvilli on limited areas of the cell surfaces, which suggested that the polarity of the cell structure was maintained even in the isolated condition.

On the 2nd day after plating, numerous regularly distributed microvilli were observed on the apical surfaces by scanning electron microscopy (Fig. 7D). Transmission electron microscopy of the longitudinal section of the cultured cells revealed that many smooth-surface vesicles were adjacent to the apical cell surface (Fig. 7A). Well-developed junctions were observed at the intercellular boundary (Figs. 7B, C).

When the cultured cells were exposed to the RR solution, RR was found only on the apical surface of the cells, but not in the intercellular spaces (Fig. 8).

Internalization of HRP by cultured bile duct cells. When cultured extrahepatic bile duct cells were exposed to a low dose of HRP, HRP was shown to be internalized by the cells. At the 5th min after exposure to HRP at $37^{\circ} \mathrm{C}, \mathrm{HRP}$ was found in the vesicles located near the apical plasma membrane. The average diameter of the vesicles was less than $0.2 \mu \mathrm{m}$ (Fig. 9A). After 15 or 30 min exposure at $37^{\circ} \mathrm{C}, \mathrm{HRP}$ was observed mostly in the intercellular spaces (Fig. 9B, C) and in the vesicles and vacuoles located near the lateral cell membrane. However, HRP was not found in either the cytoplasmic vesicles or the intercellular spaces when the cells were exposed to HRP and cultured at $4^{\circ} \mathrm{C}$.

\section{DISCUSSION}

Advanced electron microscopic study (13) revealed the presence of numerous microvilli and vesicles at the apical pole of the human intrahepatic bile duct cells, suggesting that the bile duct cells had both secretive and absorptive functions. Reabsorption of water and glucose (4) and transportation of albumin (16) by the intrahepatic bile duct cells in vivo was reported. More recently, Ishii et al. (7) demonstrated that absorption of HRP by the isolated intrahepatic bile duct cells was maintained during a short-term suspension culture. However, these studies were limited to the intrahepatic bile ducts, and the physiological functions of the extrahepatic bile duct remain to be elucidated, although the secretory function for water and electrolytes across the wall of isolated and perfused rabbit common bile duct was demonstrated (2).

In the present study, we isolated and cultured the extrahepatic bile duct cells from normal rats to determine whether the extrahepatic bile duct cells would maintain the function of fluid-phase pinocytosis or not. The isolated cells were positive for CK-19, but negative for vimentin even in mitosis, clearly showing their epithelial nature. These results are consistent with the immunohistochemical features of extrahepatic bile duct cells of rats in situ. On the other hand, vimentin expression in newly formed rat intrahepatic bile duct epithelial cells in vivo was reported (8). Such disagreement may be attributed to the following reasons: 1) intermediate filaments may be differently expressed depending on the part of rat biliary tract, even though both the intra- and extrahepatic ducts of rats are known to arise from the same part of the foregut during embryonic development or, 2) the expression of vimentin is highly influenced by the conditions of the cell culture (3).

The epithelial cells cultured on collagen-coated dishes were electron-microscopically shown to main- 

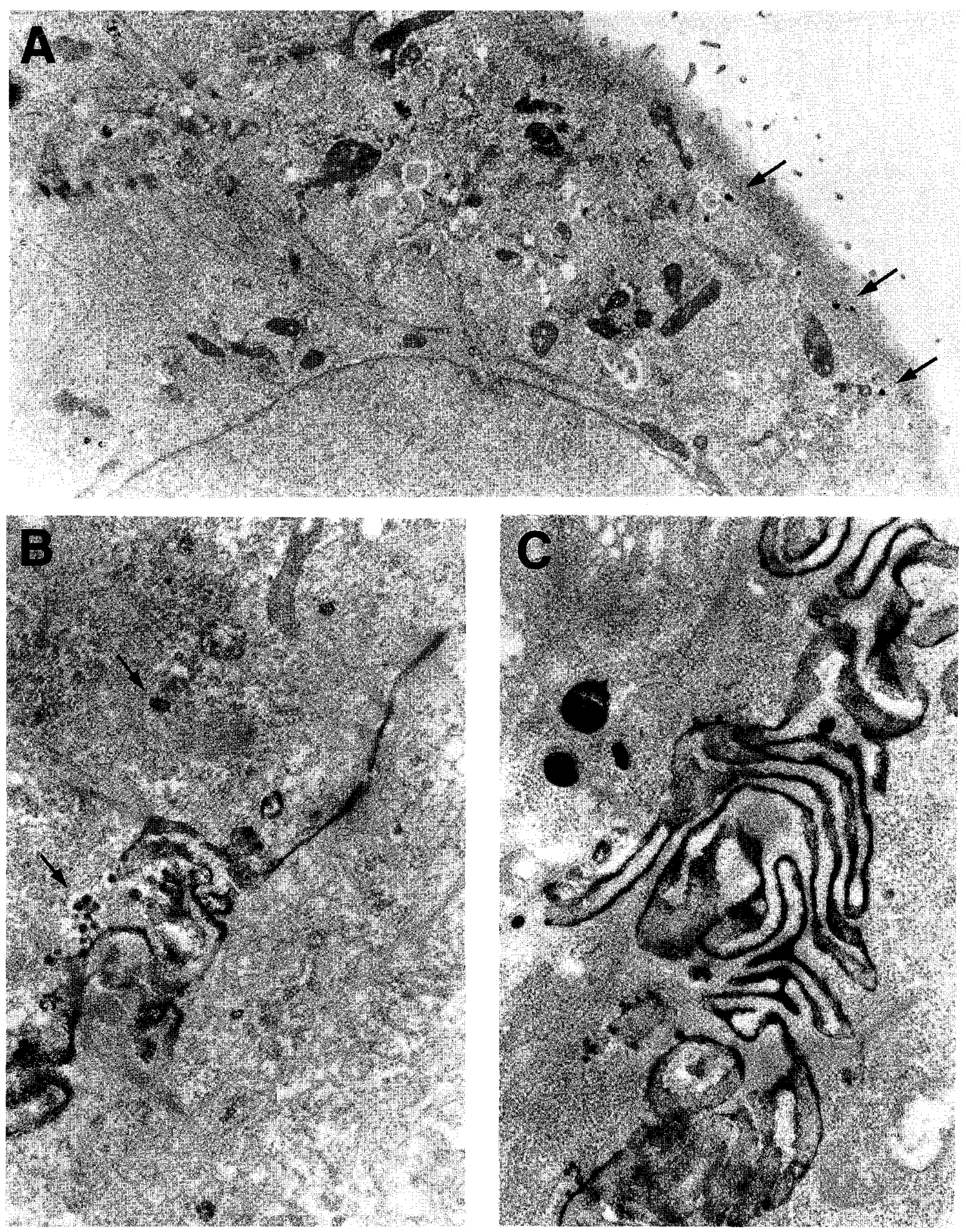

Fig. 9. Electron micrographs of the bile duct cells at the 2 nd day of culture incubated with $\mathrm{HRP}$ at $37^{\circ} \mathrm{C}$ for $5 \mathrm{~min}$ (A), $15 \mathrm{~min}$ (B), and $30 \mathrm{~min}$ (C). Arrows indicate HRP-containing vesicles. HRP-DAB reaction products are observed in the cytoplasmic vesicles and vacuoles (A). Reaction products are found in the intercellular spaces $(B$ and $C)(A: \times 5,300, B: \times 23,000, C: \times 29,000)$. 
tain their columnar configuration and cellular polarity for a few days. They possessed numerous microvilli on the apical surface and displayed junctional apparatus at the lateral surface. This may be related to the fact that the epithelial cells were isolated from the bile duct since the cell aggregates were connected to each other by means of the junctional apparatus.

When the cells were exposed to a low dose of HRP in vitro and cultured at $37^{\circ} \mathrm{C}, \mathrm{HRP}$ was clearly found in the pinocytotic vesicles located near the apical surface. The fact that HRP was not found in the vesicles when the cells were exposed to the same dose of HRP and cultured at $4{ }^{\circ} \mathrm{C}$ suggests that the uptake of HRP was the result of fluid-phase endocytosis. Later HRP was found in the intercellular spaces, in contrast to the fact that RR added to the culture media did not permeate into the intercellular spaces.

An immunofluorescence study using anti-tight junction antibody against ZO-1 (15) demonstrated the presence of tight junction networks at the apical portion of the culture cells, which indicates that the intercellular spaces are tightly sealed by tight junctions in our culture conditions. These results suggest that polarized transcytosis of HRP takes place in the extrahepatic bile duct epithelial cells in vitro from the apical to the lateral surface.

Thus we strongly suggest that the extrahepatic biliary epithelial cells can function as absorptive cells of bile constituents, as do the intrahepatic bile duct epithelial cells. Since the extrahepatic bile duct cells are different from the intrahepatic bile duct cells in the affinity to the extracellular matrix (9) and the expression of vimentin, further comparative studies of the functions of these cells are required to clarify the roles of bile duct cells and the physiology and pathobiology of the hepatobiliary system.

Acknowledgement. The authors express their gratitude to Dr. Takashi Minase for his valuable suggestion related to this work, Dr. Akira Suzuki for his helpful support and Miss Emiko Suzuki for her excellent technical assistance.

\section{REFERENCES}

1. Alpini, G., Lenzi, R., Sarkozi, L., and Tavoloni, N. (1988). Biliary physiology in rats with bile ductular cell hyperplasia. Evidence for a secretory function of proliferated bile ductules. J. Clin. Invest., 81: 569-578.

2. Chenderovitch, J. (1972). Secretory function of the rabbit common bile duct. Am. J. Physiol., 223: 695-706.

3. Greenburg, G. and Hay, E.D. (1988). Cytoskeleton and thyroglobulin expression change during transformation of thyroid epithelial to mesenchyme-like cells. Development, 102: $605-622$.
4. Guzelian, P. and Boyer, J.L. (1974). Glucose reabsorption from bile. Evidence for a biliohepatic circulation. J. Clin. Invest., 53: 526-535.

5. Hylemon, P.B., Bohdan, P.M., Sirica, A.E., Hauman, D.M., and VlaHCEVIC, Z.R. (1990). Cholesterol and bile acid metabolism in cultures of primary rat bile ductular epithelial cells. Hepatology, 11: 982-988.

6. Ishit, M., VRoman, B., and LaRusso, N.F. (1990). Morphologic demonstration of receptor-mediated endocytosis of epidermal growth factor by isolated bile duct epithelial cells. Gastroenterology, 98: 1284-1291.

7. Ishit, M., Vroman, B., and LaRusso, N.F. (1990). Fluidphase endocytosis by intrahepatic bile duct epithelial cells isolated from normal rat liver. J. Histochem. Cytochem., 38: 515524.

8. Milani, S., Herbst, H., Schuppan, D., Niedobitek, G., Kim, K.Y., and STEIN, H. (1989). Vimentin expression of newly formed rat bile duct epithelial cells in secondary biliary fibrosis. Virchows Archiv. A Pathol. Anat., 415: 237-242.

9. MAthis, G.A. and SiricA, A.E. (1990). Effects of medium and substratum on the rates of DNA synthesis in primary cultures of bile ductular epithelial cells. In Vitro Cell. Dev. Biol., 26: 113118.

10. Mori, M., Yamaguchi, J., Oyamada, M., Enomoto, K., and KANEKo, A. (1990). Cytochemical examination of the compartments involved in the transcellular transport of horseradish peroxidase in rat hepatocytes. Cell Struct. Funct., 15: 263-271.

11. Phillips, M.J., Oshio, C., Mryairi, M., Katz, H., and Smith, C.R. (1982). A study of bile canalicular contractions in isolated hepatocytes. Hepatology, 2: 763-768.

12. Rutenburg, A.M., Kim, H., Fischbein, J.W., Hanker, J.S., Wasserkrug, H.L., and Seligman, A.M. (1969). Histochemical and ultrastructural demonstration of $\gamma$-glutamyl transpeptidase activity. J. Histochem. Cytochem., 17: 517-526.

13. SASAKI, H., SCAFFner, F., and PoPper, H. (1967). Bile ductules in cholestasis: Morphologic evidence for secretion and absorption in man. Lab. Invest., 16: 84-95.

14. Schier, C., Schier, F., Voss, B., Bassewitz, B.V., and PfaUtsch, M. (1988). Characterization of human biliary duct epithelial cells in culture. Exp. Mol. Pathol., 48: 301-310.

15. Stevenson, B.R., Siliciano, J.D., Mooseker, M.S., and GOODENOUGH, D.A. (1986). Identification of ZO-1; a high molecular weight polypeptide associated with the tight junction (zonula occludens) in a variety of epithelia. J. Cell Biol., 103: $755-766$.

16. ҮокотА, S. (1984). Immunocytochemical evidence for a vesicular transport of albumin across the epithelium in the rat interlobular bile duct. Biomed. Res., 5: 303-310.

17. Watanabe, N., Tsukada, N., Smith, C.R., and Philitps, M.J. (1991). Motility of bile canaliculi in the living animal: Implications for bile flow. J. Cell Biol., 113: 1069-1080.

18. Watanabe, S. and Phillips, M.J. (1984). $\mathrm{Ca}^{2+}$ causes active contraction of bile canaliculi: Direct evidence from microinjection studies. Proc. Natl. Acad. Sci. USA, 81: 6164-6168.

19. Wheeler, H.O., Ross, E.D., and Bradley, S.E. (1968). Canalicular bile production in dogs. Am. J. Physiol., 214: 866-874.

(Received for publication, November 21, 1991

and in revised form, January 9, 1992) 